\title{
Assessment of recurrent anal fistulas treatment with platelet-rich plasma
}

\author{
Jarosław CWALIŃSKI, Jacek HERMANN, Jacek PASZKOWSKI and Tomasz BANASIEWICZ
}

Received: 6 September 2020 Accepted: 11 November 2020

\begin{abstract}
Background - Surgical treatment of recurrent anal fistulas can lead to numerous complications, including fecal incontinence. Therefore, sphincter preserving techniques are gaining more popularity. Objective - The aim of the study was to assess effectiveness of platelet-rich plasma (PRP) therapy in the patients with recurrent cryptoglandular anal fistulas. Methods - A cohort of 18 patients with anal fistulas was enrolled into a preliminary and prospective trial. They were divided into two groups consisting of eight and ten patients respectively. PRP was injected locally in all patients, however in the group II it was applied after 7 days drainage of fistulas with polyurethane foam or negative pressure wound therapy. On average, three doses of PRP were administered, but with the opportunity to double the number of applications if it was clinically justified. The patients were evaluated in an out-patient department after fortnight and then in 1, 6, and 12 months following the last PRP application. Results - Anal fistulas were closed in $4(50 \%)$ patients from the group I and in $7(70 \%)$ patients form the group II. Although, the difference between both groups was not statistically significant, PRP therapy should be preceded with fistulous tract drainage in all patients. Summarizing, that successful result was achieved in $11(60 \%)$ patients from the entire group of 18 participants. Conclusion - The rate of recurrent cryptoglandular anal fistulas closure reaching $60 \%$, after topical treatment with PRP, exceeds the results of other sphincter-saving methods of treatment. Therefore, it might become a novel method of anal fistulas therapy.
\end{abstract}

Keywords - Platelet-rich plasma; anal fistula; polyurethane foam

\section{INTRODUCTION}

Anal fistulas treatment still poses a challenge to the surgeons due to a high rate of recurrences exceeding $50 \%$ regardless of the surgical method ${ }^{(1,2)}$. What is more, multiple operations may result in damage to the anal sphincters due to inflammation and fibrosis of the tissues surrounding the anal canal in the form of so called "woody anus" with subsequent fecal incontinence, exceeding $60 \%{ }^{(3,4)}$. Therefore, traditional surgery in those patients should be replaced with more conservative methods ${ }^{(5)}$. There are sphincter preserving techniques which have been recently introduced such as ligation of intersphincteric fistula tract (LIFT), video-assisted anal fistula treatment (VAAFT), over the scope clip $\left(\mathrm{OTSC}^{\circledR}\right)$, or even less invasive e.g. fibrins and plugs, however with higher risk of recurrences ${ }^{(6-9)}$.

Local application of platelet-rich plasma (PRP), or platelet rich fibrin (PRF), might have become alternatives to aforementioned methods. The ability of enriched plasma to provide the soft tissues in vicinity of fistulous tracts with high concentration of platelet-derived growth factors with following acceleration of fistulas healing have been mentioned in few experimental reports, including application in complex and Crohn's anal fistulas ${ }^{(10-12)}$. Several technical aspects e.g. enriched plasma acquisition, volume of solution, number of applications remain to be determined. The aim of the study was to assess the local application of PRP in recurrent crypto-glandular anal fistulas.

\section{METHODS}

The study designed as a preliminary, prospective and a randomized trial to evaluate effectiveness of topical PRP was carried out from 2017 to 2019 at the Department of General, Endocrinological Surgery and Gastroenterological Oncology, Poznan University of Medical Sciences. The study group included 18 patients diagnosed with recurrent cryptoglandular anal fistula after at least one cutting procedure and with one or at most two active channels.

All investigated patients underwent digital rectal examination and probing under anesthesia supplemented by transrectal ultrasound (TRUS). Additional magnetic resonance imaging (MRI) was performed to diagnose the fistulas with more than one orifice for whom physical examination was not adequate. A total of nine patients required this assessment, three patients with transsphincteric fistulas from the group I, four patients from the second group and both patients with suprasphincteric fistulas. Patients with non crypto-glandular fistulas e.g. Crohn's, post-radiation, cancerous anal fistulas or fistulas to other pelvic organs were excluded from this study.

The procedure was preceded by enema the evening before. Next, curettage of fistulous tracts to remove the epithelium and infected granulation tissue was routinely performed. The patients were then divided into two groups. In the first group, consisted of eight patients, PRP was administered topically just immediately after fistulous tracts debridement whereas in 10 individuals from

Declared conflict of interest of all authors: none

Disclosure of funding: no funding received

Poznan University of Medical Sciences, Department of General, Endocrinological Surgery and Gastroenterological Oncology, Poznań, Poland.

Corresponding author: Jarosław Cwaliński. E-mail: cwalinski.jaroslaw@spsk2.pl 
the group II, application of the plasma was followed after 7 days of fistulas continuous drainage. For this purpose a polyurethane foam (Wound Pad, Schulke, Germany) or vacuum dressing was inserted into the fistula tract (FIGURE 1). The negative pressure wound therapy (NPWT) was indicated for fistulas with a diameter greater than $10 \mathrm{~mm}$ with concurrent abundant discharge, and it took the form of a nasogastric catheter wrapped with a polyurethane foam (Vivano, Hartmann, Germany), and inserted into a fistula through the external opening (FIGURE 2). As far as the dressing was considered, it was necessary to change the foam soaked with pus every second day in most cases, whereas negative pressure drainage was changed twice a week. Throughout the treatment, a stable negative pressure of $40-60 \mathrm{~mm} \mathrm{Hg}$ was maintained. Antibiotic prophylaxis was not routinely used either before curettage or injection of PRP. Although, both NPWT and PRP are approved for medical therapy, the novelty was the use of PRP for the treatment of anal fistulas. Therefore, the study protocol was approved by the Ethics Committee of the author's institution. Statistical analysis of all data obtained throughout the study was processed with the Statistica (Statsoft version 6.0). for Windows software.

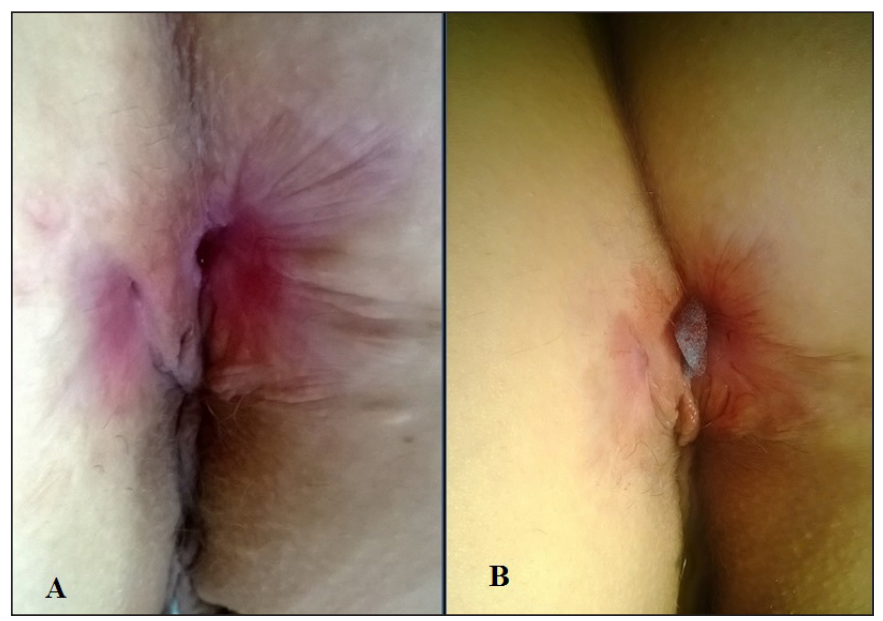

FIGURE 1. Anal fistula (A) with the tract filled with polyurethane foam (B).

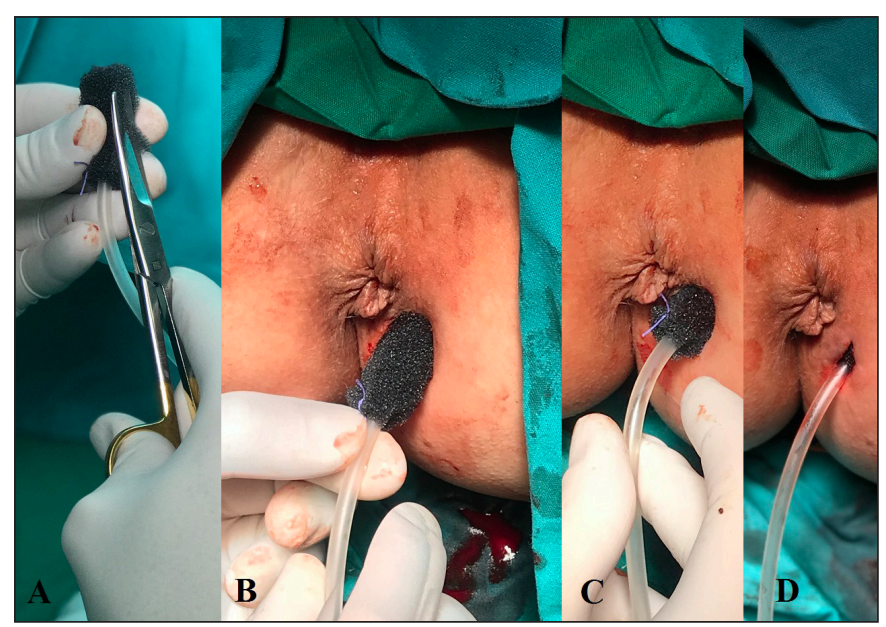

FIGURE 2. Debridement the fistula with the use of negative pressure wound therapy. Preparation of a vacuum dressing (A) and next steps of introducing the dressing into the fistula (B-D).

\section{PRP}

The volume of $1 \mathrm{~mL}$ of PRP with concentration of $10^{6}$ of platelets, was acquired from $15 \mathrm{~mL}$ of whole venous blood, through the process of gradient density centrifugation with speed of 1776 g using a commercial kit (Xerthra PRP Kit, Biovico, Poland). The concentrate in the volume of $1.5 \mathrm{~mL}$ was administered into the tissues surrounding fistulous tracts, beginning from the internal orifice towards the external one. The penetration depth was controlled with an index inserted into the anal canal or under TRUS (FIGURE 3).

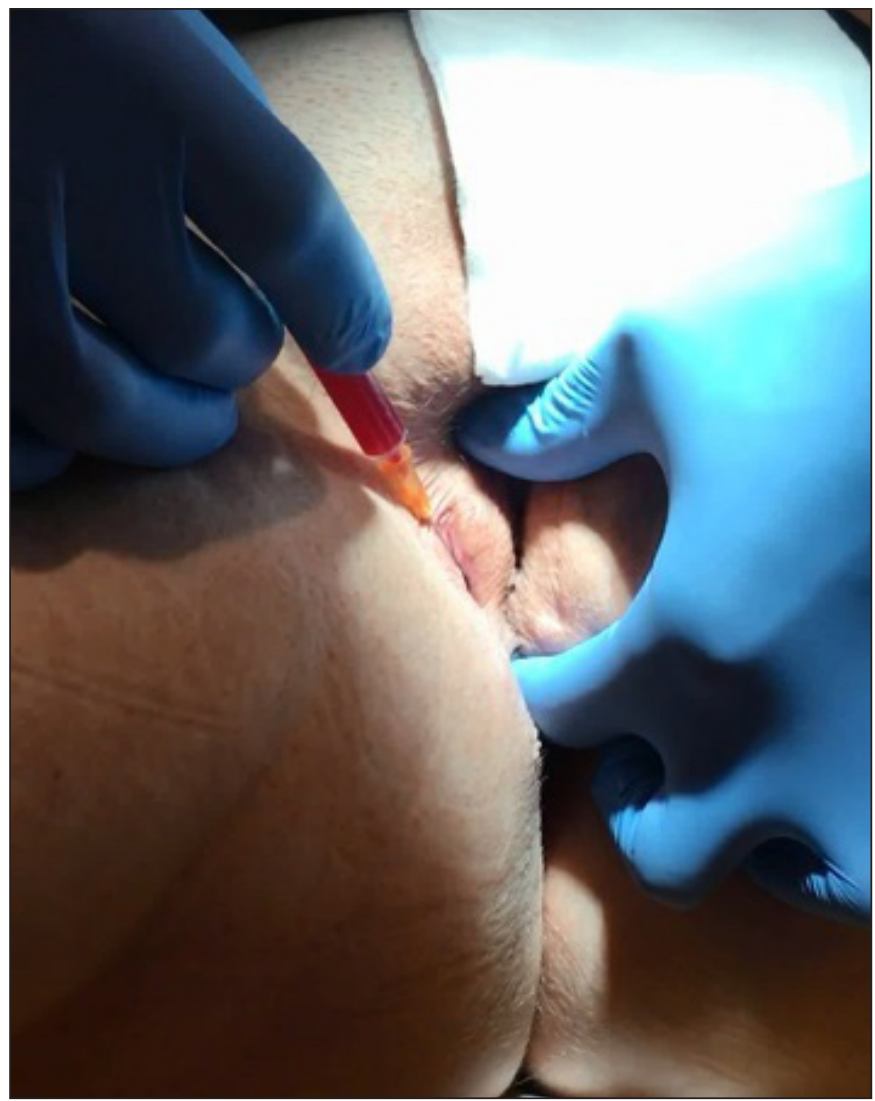

FIGURE 3. Local injection of platelet rich plasma into the tissues surrounding the fistulous tract.

According to the protocol the procedures could be repeated three times every fortnight until therapeutic effect was achieved with the opportunity to double the number of applications if it was clinically justified. If a patient did not respond to the treatment within 6 months from the last injection, an exceptional application was considered after individual evaluation based on the patients complaints and digital rectal examination. First dose of PRP was administered after admission to hospital, whereas subsequent injections were done in most cases on the basis of a proctologic clinic.

\section{Follow-up}

The patients were evaluated in an out-patient department after fortnight and then in 1, 6, and 12 months following final PRP application. That evaluation consisted of digital rectal examination, TRUS, and completion of Wexner questionnaire. In several questionable cases that examination was supplemented by MRI. 


\section{RESULTS}

The investigated group consisted of 18 patients with eight males and ten females, mean age 41 years (range: 22-67years). Recurrent transsphincteric anal fistula was diagnosed in 13 patients, whereas suprasphincteric in two and intersphincteric in three. patients. The number of previous operations in all patients ranged from three through seven, mean four, and everyone underwent at least one cutting as well as one non-cutting procedure. Mild form of faecal incontinence for gases was recognized in three patients with the Wexner score between nine and 11 . There was no significant deference between both groups regarding demographics, type of fistula, and number or method of operation (TABLE 1).

TABLE 1. Characteristics of both groups of patients before surgery.

\begin{tabular}{lcc}
\hline $\mathbf{n}$ & Group I & Group II \\
& 8 & 10 \\
\hline Men/female & $4 / 4$ & $4 / 5$ \\
Age (years) & $46.5(32-61)$ & $38.7(22-67)$ \\
$\begin{array}{l}\text { Total nuber of previous } \\
\text { procedures }\end{array}$ & $4(3-5)$ & $4(3-6)$ \\
Cutting procedures & $2(1-3)$ & $2(2-3)$ \\
Non-cutting procedures & $3(2-4)$ & $2(1-4)$ \\
Type of fistula & & \\
Intersphincteric & 1 & 2 \\
Transphincteric & 6 & 1 \\
Suprashincteric & 1 & \\
\hline
\end{tabular}

Discharge as well as gas passage through fistulous tracts were reduced in all patients from the group I after first application of PRP. In turn, fistula was closed in one patient following second injection, whereas sporadic passage of gases remained in five patients. Two patients failed to respond to PRP. Third injection of the concentrate was performed in five patients with sporadic evacuation of gases with following complete fistula closure within two through four weeks. Afterwards, fistula recurred in three of those patients in 6 to 9 weeks after the last application. Therefore, fourth and fifth injection was performed, which resulted in fistula closure in one patient. Finally, $4(50 \%)$ patients from the group I closed fistula in 12 months from the beginning of therapy.

Fistulas in the group II were healed in seven patients after two injections of PRP (FIGURE 4). The procedure was repeated in remaining three patients due to preserved, however reduced discharge. They were given another successful dosage of PRP. Recurrence was diagnosed in 1 to 4 months after the last injection in three patients with two injections, and in two after three procedures. All five patients with recurrence underwent additional application of PRP with fistula closure in two of them (FIGURE 5). Finally, fistulas were healed in $7(70 \%)$ patients form the group II. To sum up, the rate of fistula healing was not statistically significant between both groups, and it was achieved in $11(60 \%)$ patients from the entire group of 18 patients (FIGURE 6).

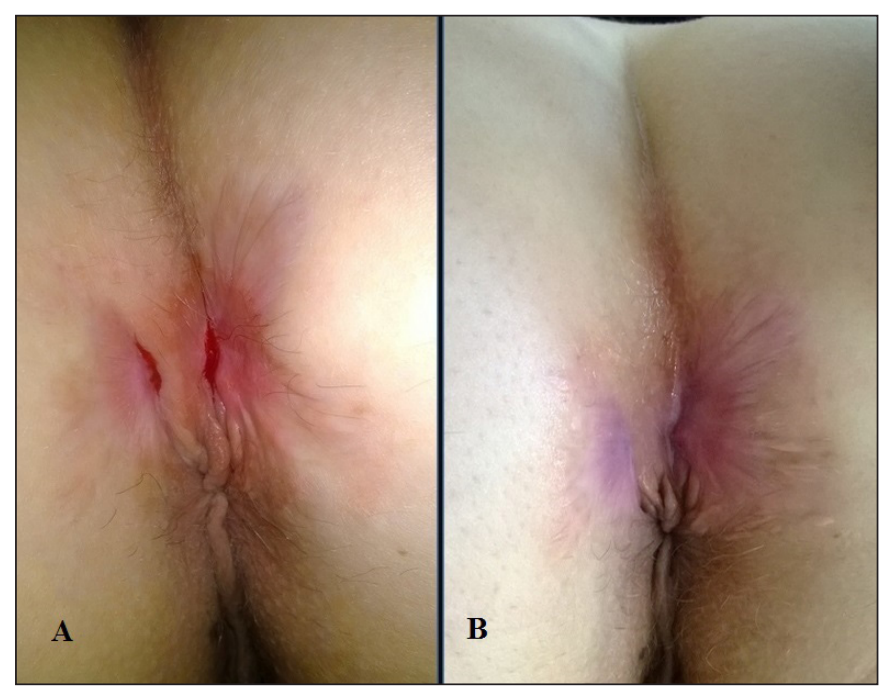

FIGURE 4. Anal fistula after removal of polyurethane foam dressing and before platelet-rich plasma (PRP) treatment (A). Complete closure of the fistula after 2 PRP injections and after another 6 weeks following final PRP application (B).

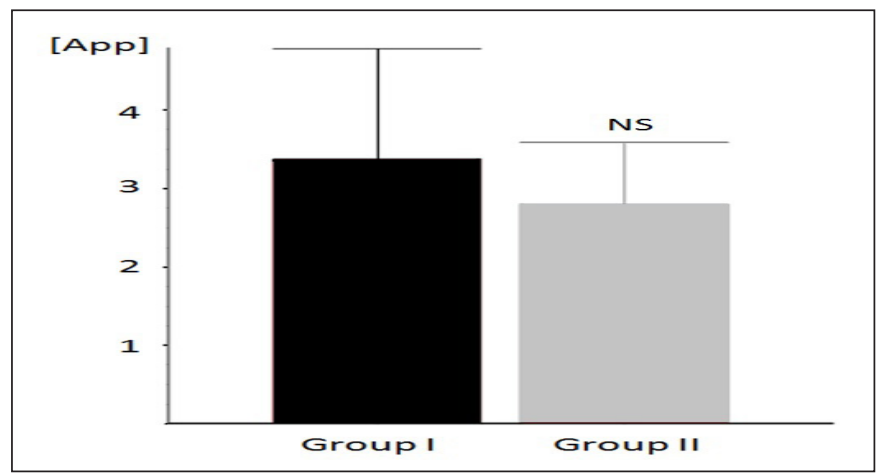

FIGURE 5. The average number of platelet-rich plasma applications [App $]$ in patients from both groups.

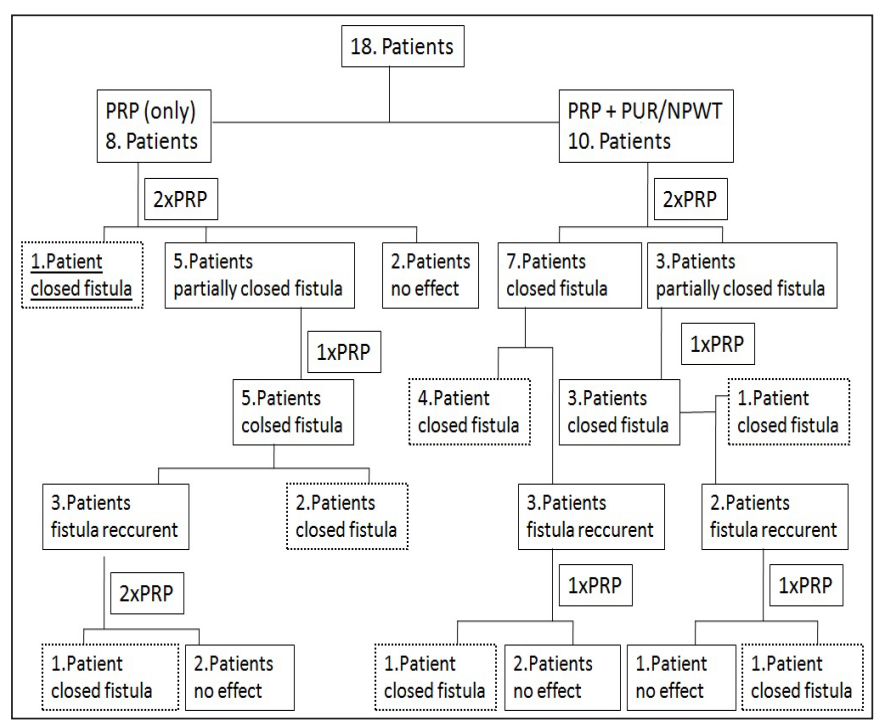

FIGURE 6. Treatment flow chart including the number of platelet-rich plasma (PRP) applications in both groups of patients. 


\section{DISCUSSION}

The main difficulties in the treatment of recurrent anal fistulas are postoperative scars and tissue fibrosis involving the anal sphincter. Fistulous canal is composed of dense, amorphous, and poorly vascularized connective tissue, and it is an essential factor preventing fistula from healing. Although the rate of recurrences after primary operations for anal fistulas is high and ranges from $30 \%$ through $65 \%$, there is scarce of reports regarding secondary interventions ${ }^{(6,13)}$. There are also no guidelines based on randomized, multicentre trials recommending surgical treatment for recurrent anal fistulas, and the existing experience is based on a small number of the investigated groups of patients, and that primary as well as secondary interventions took place in the same center. For example, MAF was used by Podetta et al., in primary operations as well as for secondary ones, regardless of similar rate of recurrences reaching $26.4 \%$ and $21.9 \%$ after both interventions respectively ${ }^{(14)}$. In turn, Wright et al., identified $20(37.7 \%)$ patients with recurrence among 53 after primary LIFT, who then underwent loose-seton placement with following either MAF or fistulotomy, resulting in fistula closure in $10(50 \%)$ patients $^{(15)}$.

Because repeated operations for recurrent anal fistulas may result in damage to the anal sphincters with following faecal incontinence, those patients require sphincter-saving methods such as LIFT, VAAFT, OTSC ${ }^{\circledast}$ or less invasive e.g. fibrins, cyanoacrylate glue, pastes or plugs. Efficacy of fibrins is estimated on 0 to $86 \%$, and it decreases with time ${ }^{(6)}$. For example, closure of anal fistulas after application of fibrin sealant Tisseel was estimated on 33-69\%(16,17) The rate of fistula healing was achieved by Basillari et al., in 71.4\% and $90.2 \%$ of patients, after primary and secondary application of Cyanoacrylate glue (N-butil-2-cyanoacrylate and methacryloxy sulfolane) respectively ${ }^{(18)}$. In turn, Moreno-Serrano et al., reported successful over-sewing of internal orifice combined with PRF in $69 \%$ of patients. That result was confirmed on MRI in $42.9 \%$ of cases $^{(11)}$. Even though these techniques have a higher rate of recurrences, all of them may be applied several times if failures are to occur. What is more, during those procedures preparation of lower value tissues within recurrent anal fistulas is not necessary. In addition, bio-products build a scaffold to promote formation of a fresh granulation tissue and finally scar within fistulous tracts ${ }^{(19,20)}$. On the other hand the impaction of the tract with fibrins or plugs may result in infiltration of neutrophils of the tissues surrounding fistulous canal. In the aftermath, outpour of cytotoxic and cytodestructive enzymes together with oxygen free radicals cause tissue necrosis with following anal fistula recurrence ${ }^{5}$. Hence, despite initial enthusiasm, those methods require further investigation to assess their efficacy ${ }^{(7)}$.
In turn, PRP is an autologous product derived from whole blood and therefore with no risk of transmitting infections, allergies, and rejections. Various cytokines freed from platelets granularities such as PDGF, TGF-B, FGF, VEGF, and IGF are responsible for creating a fibrin clot which works as a scaffolding for granulocytes, endothelial cells, and fibroblasts with following formation of well vascularized fresh granulation tissue, and finally fistula healing. The platelet concentrate was applied into the tissues surrounding fistulous tract due to its fluid consistency, slightly larger than plasma. Hence, mechanical compression of internal orifice as well as fistulous canal by edematous tissues soaked with PRP is one mode of action. On the other hand, it promotes fistula healing due to a high concentration of plateletderived growth factors ${ }^{(21,22)}$.

Local injection of PRP is a novel sphincter preserving method of treatment for the patients with recurrent anal fistulas. It is a conservative method of therapy with the opportunity to repeat the procedure as often as necessary if failures or recurrences are to occur, with low rate of morbidity. The treatment requires patience from the patients' side, as well as the doctors', because it is extended in time to repeat applications of the plasma as often as necessary. However, PRP is accepted by the patients, because it is frequently a last resort therapy.

\section{CONCLUSION}

The rate of recurrent crypto-glandular anal fistulas closure reaching $60 \%$, after topical treatment with PRP, exceeds the results of other sphincter-saving methods of treatment. Therefore, it might become a novel method of anal fistulas therapy.

\section{Authors' contribution}

All authors contributed equally to this work and approved the last version of the manuscript. Cwalinski J principal investigator responsible for the conception and partially for design of the study, acquisition of data and liable for article drafting. Hermann $\mathrm{J}$ prepared English language editing and reviewed the images. Paszkowski J contributed critical revision of the article for important intellectual content. Banasiewicz T drafted the concepts and designed the study.

\section{Orcid}

Jaroslaw Cwalinski: 0000-0001-8606-9495.

Jacek Hermann: 0000-0001-7236-0409.

Jacek Paszkowski: 0000-0002-0484-6981.

Tomasz Banasiewicz: 0000-0003-2809-6940. 
Cwaliński J, Hermann J, Paszkowski J, Banasiewicz T. Avaliação do tratamento recorrente de fístulas anais com plasma rico em plaquetas. Arq Gastroenterol. 2021;58(2):185-9.

RESUMO - Contexto - O tratamento cirúrgico de fístulas anais recorrentes pode levar a inúmeras complicações, incluindo incontinência fecal. Portanto, as técnicas de preservação do esfíncter estão ganhando mais popularidade. Objetivo - O objetivo do estudo foi avaliar a eficácia da terapia de plasma rico em plaquetas (PRP) nos pacientes com fístulas anais criptoglandulares recorrentes. Métodos - Uma coorte de 18 pacientes com fístulas anais foi inscrita em ensaio preliminar e prospectivo. Eles foram divididos em dois grupos compostos por 8 e 10 pacientes, respectivamente. PRP foi injetado localmente em todos os pacientes, porém no grupo II foi aplicado espuma de poliuretano ou terapia de feridas por pressão negativa após 7 dias de drenagem de fístulas. Em média, foram administradas três doses de PRP, mas com a oportunidade de dobrar o número de aplicações se fosse clinicamente justificado. Os pacientes foram avaliados em ambulatório após quinze dias e depois em 1, 6 e 12 meses após a última aplicação do PRP. Resultados - As fístulas anais foram fechadas em 4 (50\%) pacientes do grupo I e em 7 (70\%) pacientes do grupo II. Embora a diferença entre ambos os grupos não tenha sido estatisticamente significante, a terapia PRP deve ser precedida de drenagem do trato fístulo em todos os pacientes. Resumindo, esse resultado bem-sucedido foi alcançado em $11(60 \%)$ pacientes de todo o grupo de 18 participantes. Conclusão - A taxa de fechamento recorrente de fístulas anais criptoglandulares chegando a $60 \%$, após tratamento tópico com PRP, excede os resultados de outros métodos de tratamento que preservam o esfíncter. Portanto, pode se tornar um novo método de terapia das fístulas anais.

Palavras-chave - Plasma rico em plaquetas; fístula anal; espuma de poliuretano.

\section{REFERENCES}

1. Dudukgian $\mathrm{H}, \mathrm{Abcarian} \mathrm{H}$. Why do we have so much trouble treating anal fistula? World J Gastroenterol. 2011;17:3292-6. DOI: 10.3748/wjg.v17.i28.3292.

2. Soew-Choen F, Burnett S, Bartram CI, Nicholls RJ. Comparison between anal endosonography and digital examination in the evaluation of anal fistulas. $\mathrm{Br} \mathbf{J}$ Surg. 1991;78:445e447.

3. Farag AFA, Elbarmelgi MY, Mostafa M, Mashhour AN. One stage fistulectomy for high anal fistula with reconstruction of anal sphincter without fecal diversion. Asian J Surg. 2019;42:792-6. DOI: 10.1016/j.asjsur.2018.12.005.

4. Antonio A, Pérez-Legaz L, Moya P, Armañanzas L, Lacueva J, Pérez-Vicenten $\mathrm{F}$, et al. Fistulotomy and sphincter reconstruction in the treatment of complex fistula-in-ano: long-term clinical and manometric results. Ann Surg. 2012;255:9359. DOI:10.1097/SLA.0b013e31824e9112.

5. Palumbo VD, Tralongo P, Di Trapani B, Carini F, Tomasello G. The use of Argentum-Quartz ${ }^{\mathbb{B}}$ solution in primary or recurrent perianal fistulas: first experience on three cases. Clin Ter. 2019;170:e328-e31. DOI: 10.7417/CT.2019.2155.

6. Kontovounisios C, Tekkis P, Tan E, Rasheed S, Darzi A, Wexner SD. Adoption and success rates of perineal procedures for fistula-in-ano: a systematic review. Colorectal Dis. 2016;18:441-58. DOI: 10.1111/codi.13330

7. Akiba RT, Rodrigues FG, da Silva G. Management of Complex Perineal Fistula Disease. Clin Colon Rectal Surg. 2016;29:92-100. DOI: 10.1055/s-0036-1580631.

8. Fung AK, Card GV, Ross NP, Yule SR, Aly EH. Operative strategy for fistula-in-ano without division of the anal sphincter. Ann R Coll Surg Engl. 2013;95:461-7. DOI:10.1308/003588413X13629960048956.

9. Amor IB, Lainas P, Kassir R, Chenaitia H, Dagher I, Gugenheim J. Treatment of complex recurrent fistula-in-ano by surgery combined to autologous bone marrow-derived mesenchymal stroma cells and platelet-rich plasma injection. Int J Colorectal Dis. 2019;34:1795-9. DOI: 10.1007/s00384-019-03367-2.

10. Alves R, Grimalt R. A Review of Platelet-Rich Plasma: History, Biology, Mechanism of Action, and Classification. Skin Appendage Disord. 2018;4:18-24. DOI: $10.1159 / 000477353$.

11. Moreno-Serrano A, García-Díaz JJ, Ferrer-Márquez M, Alarcón-Rodríguez R, Álvarez-García A, Reina-Duarte Á. Using autologous platelet-rich plasma for the treatment of complex fistulas. Rev Esp Enferm Dig. 2016;108:123-8. DOI: 10.17235/reed.2016.3946/2015.

12. Göttgens KW, Smeets RR, Stassen LP, Beets GL, Pierik M, Breukink SO. Treatment of Crohn's disease-related high perianal fistulas combining the mucosa advancement flap with platelet-rich plasma: a pilot study. Tech Coloproctol. 2015;19:455-9. DOI: 10.1007/s10151-015-1311-8.
13. Corson JD, Williamson RCN, eds. Surgery. London: Mosby; 2001: 12 -14. British Journal of Surgery, Volume 88 (9) - Sep 1, 2001 [Internet] Available from: deepdyve.com/lp/wiley/surgery-j-d-corson-r-c-n-williamson-eds-297-254-mm-pp1660-illustrated-8JC55Ok2u0

14. Podetta M, Scarpa CR, Zufferey G, Skala K, Ris F, Roche B, et al. Mucosal advancement flap for recurrent complex anal fistula: a repeatable procedure. Int J Colorectal Dis. 2019;34:197-200. DOI: 10.1007/s00384-018-3155-y.

15. Wright M, Thorson A, Blatchford G, Shashidharan M, Beaty J, Bertelson N, et al. What happens after a failed LIFT for anal fistula? Am J Surg. 2017;214:1210-13. DOI: 0.1016/j.amjsurg.2017.08.042

16. Zmora O, Mizrahi N, Rotholtz N, Pikarsky AJ, Weiss EG, Nogueras JJ, et al. Fibrin glue sealing in the treatment of perineal fistulas. Dis Colon Rectum. 2003;46:584-9. DOI: 10.1007/s10350-004-6612-3.

17. Sentovich SM. Fibrin glue for anal fistulas: long-term results. Dis Colon Rectum. 2003;46:498-502. DOI: 10.1007/s10350-004-6589-y.

18. Barillari P, Basso L, Larcinese A, Gozzo P, Indinnimeo M. Cyanoacrylate glue in the treatment of ano-rectal fistulas. Int J Colorectal Dis. 2006;21:791-4. DOI: 10.1007/s00384-006-0090-0.

16. Zmora O, Mizrahi N, Rotholtz N, Pikarsky AJ, Weiss EG, Nogueras JJ, et al. Fibrin glue sealing in the treatment of perineal fistulas. Dis Colon Rectum. 2003;46:584-9. DOI: 10.1007/s10350-004-6612-3.

17. Sentovich SM. Fibrin glue for anal fistulas: long-term results. Dis Colon Rectum. 2003;46:498-502. DOI: 10.1007/s10350-004-6589-y.

18. Barillari P, Basso L, Larcinese A, Gozzo P, Indinnimeo M. Cyanoacrylate glue in the treatment of ano-rectal fistulas. Int J Colorectal Dis. 2006;21:791-4.

19. de la Portilla F, Rada R, Jiménez-Rodríguez R, Díaz-Pavón JM, Sánchez-Gil JM. Evaluation of a new synthetic plug in the treatment of anal fistulas: results of a pilot study. Dis Colon Rectum. 2011;54:1419-22. DOI: 10.1097/DCR. $0 \mathrm{~b} 013 \mathrm{e} 31822 \mathrm{c} 4 \mathrm{~d} 59$

20. Jarrar A, Church J. Advancement flap repair: a good option for complex anorectal fistulas. Dis Colon Rectum. 2011;54:1537-41. DOI: 10.1097/ DCR.0b013e31822d7ddd.

21. Dhurat R, Sukesh M. Principles and Methods of Preparation of Platelet-Rich Plasma: A Review and Author's Perspective. J Cutan Aesthet Surg. 2014;7:189-97. DOI: 10.4103/0974-2077.150734.

22. Lacci KM, Dardik A. Platelet-Rich Plasma: Support for Its Use in Wound Healing. Yale J Biol Med. 2010;83:1-9. 